\title{
The Interaction between Labor Productivity and Competitiveness in Vietnam
}

\author{
Nguyen Thi DONG ${ }^{1}$, Tran Thi Ai DIEM², Bui Thi Hong CHINH ${ }^{3}$, Nguyen Thi Diu HIEN ${ }^{4}$
}

Received: August 01, 2020 Revised: September 30, 2020 Accepted: October 15, 2020

\begin{abstract}
This study measures the relationship between labor productivity and national competitiveness. Through the shift- share analysis method, the paper has separated labor productivity into three factors: static shift effect, dynamic shift effect and endogeneous effect. Next, in combination with the Granger causality test, the paper examines the relationship between the factors constituting labor productivity and competitiveness during the period from 2005 to 2017. Research data is collected from General Statistics Office and annual global competitiveness reports. The results show that the interaction between labor productivity with global competitiveness index (GCI) in Vietnam has similar variation. Nevertheless, when separating labor productivity into three effects, this relationship shows more clearly that the impact of labor productivity on GCI scores is mainly caused by endogeneous effect, not by static shift effect or dynamic shift effect. Therefore, in order to improve its competitiveness, Vietnam should focus on a number of solutions: reforming the education system towards developing thinking capacity and creative capacity; fostering industrial manners to create dynamic and flexible workers; building the State with sufficient capacity to implement consistent and transparent policies; formulating policies to attract all economic sectors so that they actively participate in the field of human resource training for the country.
\end{abstract}

Keywords: Global Competitiveness Index, Labor Productivity, Competitiveness, Vietnam

JEL Classification Code: J01, J24, O40

\section{Introduction}

Labor productivity is both a key factor in determining the competitiveness and long-term survival of an enterprise and also a foundation for increasing income, creating a good working environment for employees. Increasing labor productivity is about improving the quality of life and ensuring a better society. The role of labor productivity has been confirmed in times of economic crisis. At that time, the developed countries had discovered the fastest way to

${ }^{1}$ First Author and Corresponding Author. Banking Academy - Phu Yen Campus, Vietnam [Postal Address: 441 Nguyen Hue, Tuy Hoa City, Phu Yen Province, Vietnam] Email: dongnt@hvnh.edu.vn

²Banking Academy - Phu Yen Campus, Tuy Hoa City, Vietnam. Email: diemtta.py@hvnh.edu.vn

33anking Academy - Phu Yen Campus, Tuy Hoa City, Vietnam. Email: chinhbth.py@hvnh.edu.vn

4Banking Academy - Phu Yen Campus, Tuy Hoa City, Vietnam. Email: hienntd.py@hvnh.edu.vn

(c) Copyright: The Author(s)

This is an Open Access article distributed under the terms of the Creative Commons Attribution Non-Commercial License (https://creativecommons.org/licenses/by-nc/4.0/) which permits unrestricted non-commercial use, distribution, and reproduction in any medium, provided the original work is properly cited. recover the economy was to develop technology and improve productivity.

After changing to market mechanism, under the influence of market forces and competition pressure, Vietnamese enterprises, especially state-owned enterprises, have recognized the important role of labor productivity in their existence and development. As a result, after nearly 35 years of innovation and international intergration, Vietnam has made remarkable progress in increasing the labor productivity of the entire economy. From a country in the group of the poorest countries in the world, Vietnam has now moved out of underdevelopment to become a middle-income country with a dynamic market economy. However, the broad growth model that Vietnam has chosen has no longer been able to maintain high and sustainable growth, leading to weak efficiency and competitiveness of the economy. With the desire that labor productivity growth must be realised to promote national competitiveness, the paper aims to assess the relationship between labor productivity growth and competitiveness. Thereby, the paper gives a number of recommendations on improving labor productivity associated with the goal of increasing national competitiveness. 


\section{Literature Review}

\subsection{The Concept of Labor Productivity}

Krugman (1994) once said: "productivity is not everything, but in the long run it is almost everything". When it comes to productivity, it is often understood in the sense of "working smarter" instead of "working harder". Productivity reflects an organization's ability to use new ideas, innovate technology and business models to create products (McGowan, Andrews, Criscuolo, \& Nicoletti, 2015).

Labor productivity, in the simplest sense, is a measure of an economy's capacity to produce output (goods and services) from a given set of inputs (labor, capital, natural resources etc.) (CMA, 2015). For workers, productivity can be increased in the short or long term, either through lessons learned or through their own self-learning (Le, Duy, \& Ngoc, 2019). In each economic entity (such as companies and other types of businesses), labor productivity is measured by the amount of product produced per unit of time or the time required to produce a unit of product. In the whole country, labor productivity is expressed as social labor productivity (LP) which is determined on the basis of gross domestic product (GDP) or gross natioal product (GNP) divided by the number of employees working in each period in the economy (L).

$$
L P=\frac{G D P}{L}
$$

An economy with high labor productivity can create a lot of value through the efficient distribution of inputs. Increasing productivity means slowing down cost increases, leading to improved price competitiveness, facilitating company development and increasing income for employees Nguyen, Nguyen, Ngo, \& Nguyen, 2019). Thus, with the meaning of "working smarter", improving labor productivity is considered a long-term goal of economic policy towards a sustainable economic growth.

\subsection{The Concept of Competitiveness}

Competition is a struggle between suppiers to use tools of prices, quality, product design of after-sales service etc to attract customers. Thereby, the suppliers gain more market share, which means that they have competed successfully (CMA, 2015). Competitiveness is the ability to maintain and generate relatively high income from the factors of production of the firm, the industry or the country. At the same time, the factors of production are used at a sustainable level in today's competitive environment (Ivanová \& Čepel, 2018). National competitiveness, as assessed by economists at the World Economic Forum, is a set of institutions, policies and factors that can affect productivity, creating prosperity for the economy (Schwab \& Sala-i-Martin, 2017). National competitiveness can also be deteminedby the productivity of firms operating in that economy, since it is the firms that create competitiveness advantage, and the government creates a business environment for businesses to grow (Duda, Gasior, \& Alebaite, 2017; Sergej, 2016; Soltes \& Gavurova, 2015; Virglerova, Dobeš, \& Vojtovič, 2016).

A country's competitiveness does not develop from the availability of natural resources, labor, and capital in the economy, but it depends on the efficiency of its use. To evaluate more specifically the ability to provide prosperity for people in each country, the World Economic Forum (WEF) published the Global Competitiveness Report (GCR). The GCR was first published in 1979 and has now been used in many documents for many academic studies as well as many articales in prestigious journals. In the beginning, WEF aims to help countries improve their competitiveness by setting development strategies and policies. Since 2005 up to now, WEF has used Global Competitivenss Index (GCI) as a tool to measure the effects of macro and micro economic factors on the competitiveness of each country. GCI is calculated through 14 indicators, divided into 12 groups including: institutions, infrastructure, macroeconomic environment, health and primary education, higher education and training, goods market efficiency, labor market efficiency, financial market development, technological readiness, market size, business sophistication and innovation. Those are the important factors for the long-term prosperity of each nountry. Therefore, GCI shows a general and comprehensive picture of strengths and weaknesses of economies of the countries. Since then, the governments themselves identify opportunities and challenges to set the development direction (Schwab \& Sala-i-Martin, 2017) (See Table 1).

Since 2018, with the strong impact of the industrial revolution and a fragile economic recovery, the WEF has changed its method of calculating GCI. The new index is called GCI 4.0. This index focuses more on promoting long-term growth and improving people's income. Due to different approaches, it is not possible to compare the previous GCI and GCI 4.0. Therefore, for consistency in the study, the authors only use GCI data for the period from 2005 to 2017. 
Nguyen Thi DONG, Tran Thi Ai DIEM, Bui Thi Hong CHINH, Nguyen Thi Diu HIEN/

Journal of Asian Finance, Economics and Business Vol 7 No 11 (2020) 619-627

Table 1: Ranking and scores of GCI Vietnam in the period from 2005 to 2017

\begin{tabular}{|l|c|c|c|}
\hline Year & Scores (maximum: 7) & Rank & Number of countries participating in the rating \\
\hline 2005 & 3.91 & 74 & 117 \\
\hline 2006 & 3.89 & 77 & 125 \\
\hline 2007 & 4.04 & 68 & 131 \\
\hline 2008 & 4,1 & 70 & 134 \\
\hline 2009 & 4,0 & 75 & 133 \\
\hline 2010 & 4,3 & 59 & 139 \\
\hline 2011 & 4,2 & 65 & 142 \\
\hline 2012 & 4,1 & 75 & 144 \\
\hline 2013 & 4.2 & 70 & 148 \\
\hline 2014 & 4.32 & 68 & 144 \\
\hline 2015 & 4.3 & 56 & 140 \\
\hline 2016 & 4.31 & 60 & 138 \\
\hline 2017 & 4.4 & 55 & 137 \\
\hline
\end{tabular}

Source: The Global Competitiveness Report, WEF

\subsection{Relationship Between Labor Productivity and Competitiveness}

The relationship between labor productivity and national competitiveness had been analyzed by Porter (2008) on the basis of many different perspectives and trends to answer the question: which factors have the most influence on national competitiveness? The first point of view argues that national competitiveness is a macroeconomic phenomenon, driven by variables such as exchange rates, interest rates and national deficits or government policy. According to Porter, historical practice has proven that even though Italy and Korea have both high interest rates and government deficits, or Germany and Switzeland occasionally increase domestic currencies and their governments rarely intervene directly in export industries, people in these countries still enjoy the rapidly increasing standard of living. The second perspective explains that competitiveness depends on cheap and redundant labor. Porter gives evidence that Germany, Switzeland and Sweden all flourish even when there are shortages of labor and very high wages. India and Mexico, meanwhile, both have low wages and labor costs, but fail to prove their appeal. In addition, there is still a view that there is a strong link between competitiveness with abundant natural resources, but with that point of view, they will not be able to explain the success of countries that are very limited in terms of resources such as Germany, Japan, Switzerland, Italy or Korea.

Porter (2008) stated that the most influencing factor for national competitiveness is labor productivity. In the current globalization trend, the advantage of production inputs such as cheap labor and resources are only necessary conditions, not sufficient conditions for competition. Instead, the factors of creative capacity, managerial talent and the connection between customers and suppliers are important factors that determine competitiveness. In particular, in developing countries where capital is scarce, increasing labor productivity is the decisive factor in the income of workers, as the engine of national economic growth and is an important basis in making policies for businesses and the economy. Besides Porter (2008), many economists approach this relationship through empirical research. Auzina-Emsina (2014) used data from European Union countries to study the relationship between labor productivity, economic growth and competitiveness. The author concluded that labor productivity and economic growth are the key factors to maintain and enhance the competitiveness of countries in the global market.

Mihaela (2016) applied a self-regression model with data from 42 counties of Romania to study the factors affecting the competitiveness of the economy in the period from 2006 to 2014. Contrary to the earlier assumption that the competitiveness of Romania's economy does not depend on human capital investment and innovation, the author confirmed that the implementation of policies on reducing structural unemployment, improving labor skills to meet the needs of the labor market, improving the education system, lifelong learning and poverty control and other aspects will create a foundation for enhancing national competitiveness. Carayannis and Grigoroudis (2014) used a regression model 
following the principles of multi-objective mathematical programming to study the dynamic linkages among innovation, productivity and competitiveness. The results indicated that overall, there is no significant gap between innovation, productivity and competitiveness. However, if each specific country is considered then there are still differences in the research results.

In addition to the macro level studies, the interaction between labor productivity and competitiveness has also been studied at a micro level. Borja-Bravo, García-Salazar, and Skaggs (2013) applied spatial and inter-temporal modeling to analyze the impact of increased tomato yields in Mexico on fresh tomato markets in North America. The model shows that of the three countries that export fresh tomatoes (US, Mexico, Canada), which has a higher yield of fresh tomatoes is the country with better competitiveness in terms of market share for tomatoes. Nam (2013) used statistical methods and discriminant functions to analyze factors affecting the competitiveness of SMEs in Can Tho, Vietnam. The research results show that labor productivity is one of the most influential and decisive factors to the competitiveness of small and medium enterprises in this province.

\section{Methodology}

\subsection{Method of Calculating Labor Productivity Growth}

Shift-share analysis method considers the process of increasing labor productivity through the movement of economic structure and the level of labor restructuring by sectors. Calling LP is the total of social labor productivity ; $\mathrm{i}$ corresponds to manufacturing sectors $(\mathrm{i}=1, \ldots, \mathrm{n}$, where $\mathrm{n}$ is the number of sectors); $\mathrm{S}_{\mathrm{i}}$ is the proportion of workers working in sector $i ; 0$ and t are the starting and ending points of the research period. The total of labor productivity at time $\mathrm{t}$ in formula (1) can be developed into:

$$
L P^{t}=\frac{G D P^{t}}{L^{t}}=\sum_{i=1}^{n} \frac{G D P_{i}^{0} \cdot L_{i}^{t}}{L_{i}^{t} \cdot L^{t}}=\sum_{i=1}^{n} L P_{i}^{t} \cdot S_{i}^{t}
$$

Using equation (2) to calculate the difference in the aggregate of labor productivity at times 0 and $\mathrm{t}$ (Timmer \& Szirmai, 2000):

$$
\begin{aligned}
& L P^{t}-L P^{0}=\sum_{i=1}^{n} L P_{i}^{0}\left(S_{i}^{t}-S_{i}^{0}\right)+=\sum_{i=1}^{n}\left(L P_{i}^{t}-L P_{i}^{0}\right) . \\
&\left(S_{i}^{t}-S_{i}^{0}\right)+\sum_{i=1}^{n}\left(L P_{i}^{t}-L P_{i}^{0}\right) \cdot S_{i}^{0}
\end{aligned}
$$

Divide the 2 sides of the equation (3) by $\mathrm{LP}^{0}$, we have the formula for calculating the growth of social labor productivity (GLP)

$$
\begin{aligned}
G L P_{t} & =\frac{L P^{t}-L P^{0}}{L P^{0}} \\
= & \frac{\sum_{i=1}^{n} L P_{i}^{0}\left(S_{i}^{t}-S_{i}^{0}\right)}{L P^{0}}+\frac{\sum_{i=1}^{n}\left(L P_{i}^{t}-L P_{i}^{0}\right)\left(S_{i}^{t}-S_{i}^{0}\right)}{L P^{0}} \\
& +\frac{\sum_{i=1}^{n}\left(L P_{i}^{t}-L P_{i}^{0}\right) S_{i}^{0}}{L P^{0}}
\end{aligned}
$$

This separation method was developed by Fabricant (1942), which he used to measure the number of labor per unit produced. Later, Syrquin (1984), Fagerberg (2000) applied Fabricant's method, but they studied in the inverse direction: measuring the quantity of product produced per unit of labor.

The above equation evaluates the speed of social labor productivity growth based on three parts: the first side on the right of the equation denotes the static shift effect, the second side denotes the dynamic shift effect and the third is endogeneous effect.

The static shift effect measures productivity growth through labor restructuring towards more productive industries. It uses weight as the value of the labor productivity of the industry in the first year of the study period. According to Syrquin and Chenery (1986), the ratio of capital to labor of light industries is lower than that of heavey ones. At the same time, since capital-intensive industries tend to have higher labor productivity, the shift of labor from light industry to heavy industry will tend to increase productivity. Static shift effect, moreover, plays an important role to developing countries, especially agricultural countries where population density is high and idle or redundant labor is common. The shift of labor from agricultural sector with low labor productivity to industrial ones with higher labor productivity is therefore considered as "a structural bonus" for developing countries (Timmer \& Szirmai, 2000). That means the hypothesis of structural bonus is based on expectation that contribution from static shift effect to growth of social labor productivity is positive:

$$
\sum_{i=1}^{n} L P_{i}^{0}\left(S_{i}^{t}-S_{i}^{0}\right)>0
$$

Unlike static shift effect that only targets a highly productive industry, the dynamic shift effect measures productivity growth based on changes in both labor productivity and labor productivity growth. If the labor move to industries where both labor productivity and its growth rate are high, it may make the aggregate labor productivity increase and the positive interaction effect will be amplified. Conversely, if labor shift from dynamically developed industries with high productivity growth to 
Nguyen Thi DONG, Tran Thi Ai DIEM, Bui Thi Hong CHINH, Nguyen Thi Diu HIEN /

Journal of Asian Finance, Economics and Business Vol 7 No 11 (2020) 619-627

traditional industries with low rates of productivity growth, then the economy could experience negative growth. Baumol (1967) called this the "structural burden" in the process of redistributing the workforce by industry. Thus, the dynamic shift effect will be negative when a structural burden appears:

$$
\sum_{i=1}^{n}\left(L P_{i}^{t}-L P_{i}^{0}\right)\left(S_{i}^{t}-S_{i}^{0}\right)<0
$$

The last effect is endogeneous effect. It reflects the improved labor productivity in the condition of the labor structure not changing, the size of the employees working in each sector is unchanged during the study period. In other words, the endogeneous effect is the result of renovation, application of technological advances, improvement of labor skills and institutional factor (Anh, 2007). If referenced with the concept of total factor productivity, the endogeneous effect can also be considered as total factor productivity (Dong, 2018; Te \& Dong, 2013)

\subsection{Apply the Granger Method}

The Graner causality test is used in this article to measure the interaction between labor productivity and competitiveness. This is a fairly simple method, but it is very practical. It is used to prove whether there exists a relationship between the two factors. According to Granger (1969), changes in the past can predict the future, but in the opposite direction, the future cannot be used to predict what happened in the past. Consequently, when performing the Granger test for the two variables of competitiveness (GCI) and labor productivity growth (GLP), if the past values or the lag values of GLP can predict GCI then we say that GLP is the cause of GCI. Similarly, if the past or lag values of GCI can predict GLP then we say GCI is the cause of GLP.

To test whether the causal relationship between the two variables GLP and GCI, the following two equations are used:

$$
\begin{aligned}
& G C I_{t}=\varphi_{0}+\sum_{p=1}^{n} \alpha_{p} G L P_{t-p}+\sum_{q=1}^{n} \beta_{p} G C I_{t-q}+u_{1 t} \\
& G L P_{t}=\varphi_{1}+\sum_{p=1}^{n} \lambda_{p} G L P_{t-p}+\sum_{q=1}^{n} \delta_{p} G C I_{t-q}+u_{2 t}
\end{aligned}
$$

In which, GLP and GCI are time series, $\mathrm{n}$ is the delay lag length and $\mathrm{u}$ is an error term in the model. The Granger test will be conducted on the basis of the following hypotheses:

Equation (7): hypothesis $\mathrm{H}_{0}: \alpha_{1}=\alpha_{2}=\ldots=\alpha_{\mathrm{p}}=0$

Equation (8): hypothesis $\mathrm{H}_{0}: \delta_{1}=\delta_{2}^{2}=\ldots=\delta_{\mathrm{q}}^{\mathrm{p}}=0$

The causal relationship between GCI and GLP can be one of the following four cases:
- Case 1: If $\alpha_{\mathrm{p}}$ is non-zero and statistically significant, $\delta_{\mathrm{q}}$ is not significant, it can be concluded that GLP is the cause of GCI variation.

- Case 2: If $\alpha_{\mathrm{p}}$ is not significant, $\delta_{\mathrm{q}}$ is non-zero and statistically significant, it can be concluded that GCI is the cause of GLP variation.

- Case 3: If both $\alpha_{\mathrm{p}}$ and $\delta_{\mathrm{q}}$ are non-zero and statistically significant, it can be concluded that GLP and GCI interact with each other.

- Case 4: If both $\alpha_{\text {and }} \delta_{\text {q }}$ are not significant, it can be concluded that GLP and GCI are independent of each other.

The Granger causality test assumes that when the other factors are constant, the time series data is the only data series that contains all the appropriate information to account for the change in the relationship between the two variables. According to Gujarati (2004), before performing the Granger test, it is necessary to pay attention to the time series conditions to ensure efficiency in the regression. That is, the variables in the research model must be stationary chains to ensure that they have a long and stable relationship with each other. In addition, the direction of causality may depend on the number of variables in the model. In other words, the Granger test results are very sensitive to the choice of variable lags. If the selected lags is less than the actual lags, omitting the appropriate lags variable may bias the results. Conversery, if the selection of the lags is greater than necessary, an inappropriate number of lags variables will make the estimation ineffective. The calculation of the optimal lags can be performed via the Akaike or Schwarz information criterion (AIC or SIC) provided that the lags value is chosen such that the AIC or SIC is smallest.

\subsection{Research Data}

To apply the shift share analysis method, the study uses data on Vietnam's labor structure and labor productivity in the period from 2005 to 2017. GDP is in current price and all thes figures are taken from the Vietnam Statistical Yearbook over the years (GSO, 2020). To assess competitiveness, the authors used the global competitiveness index, taken from the competitiveness report over the years.

\section{Research Results}

\subsection{Labor Productivity Growth}

The results of calculating labor productivity are considered in both aspects: the rate of increase (decrease) of each factor contributing to the growth rate of social labor productivity in each year; and the proportion, representing the contribution rate of these factors to the increase in social labor productivity (See Table 2). 
Table 2: Vietnam's labor productivity growth through shift share analysis method

\begin{tabular}{|l|c|c|c|c|c|c|c|}
\hline \multirow{2}{*}{ Year } & \multicolumn{4}{|c|}{ Percentage point } & \multicolumn{3}{c|}{ Proportion (\%) } \\
\cline { 2 - 7 } & $\begin{array}{c}\text { Static shift } \\
\text { effect }\end{array}$ & $\begin{array}{c}\text { Dynamic } \\
\text { shift effect }\end{array}$ & $\begin{array}{c}\text { Endogeneous } \\
\text { effect }\end{array}$ & $\begin{array}{c}\text { Labor } \\
\text { productivity } \\
\text { growth }\end{array}$ & $\begin{array}{c}\text { Static shift } \\
\text { effect }\end{array}$ & $\begin{array}{c}\text { Dynamic } \\
\text { shift effect }\end{array}$ & $\begin{array}{c}\text { Endogeneous } \\
\text { effect }\end{array}$ \\
\hline 2005 & 0.52 & 0.18 & 4.98 & 5.68 & 9.24 & 3.13 & 87.63 \\
\hline 2006 & 0.74 & 0.04 & 2.32 & 3.10 & 23.83 & 1.23 & 74.94 \\
\hline 2007 & 0.80 & -0.03 & 2.77 & 3.54 & 22.65 & -0.90 & 78.25 \\
\hline 2008 & 0.24 & 0.04 & 6.41 & 6.69 & 3.56 & 0.57 & 95.87 \\
\hline 2009 & 0.30 & 0.02 & 2.03 & 2.35 & 12.78 & 0.92 & 86.29 \\
\hline 2010 & 0.71 & 0.04 & 2.51 & 3.26 & 21.79 & 1.26 & 76.95 \\
\hline 2011 & 0.36 & 0.00 & 3.73 & 4.08 & 8.77 & -0.10 & 91.32 \\
\hline 2012 & 0.24 & 0.02 & 4.21 & 4.47 & 5.30 & 0.51 & 94.19 \\
\hline 2013 & 0.17 & 0.03 & 2.35 & 2.56 & 6.85 & 1.01 & 92.14 \\
\hline 2014 & 0.13 & 0.01 & 2.38 & 2.51 & 5.01 & 0.42 & 94.57 \\
\hline 2015 & 0.75 & -0.01 & 1.06 & 1.81 & 41.79 & -0.32 & 58.53 \\
\hline 2016 & 0.75 & -0.05 & 1.21 & 1.90 & 39.37 & -2.75 & 63.38 \\
\hline 2017 & 0.52 & 0.05 & 2.62 & 3.19 & 16.31 & 1.41 & 82.28 \\
\hline
\end{tabular}

Sources: Authors' calculation from the figures of GSO

According to the above method, the factors contributing to Vietnam's labor productivity growth in the period from 2005 to 2018 changed significantly. In the period from 2005 to 2014 , the factors of endogeneous growth such as natural resources, technology, technical innovation, management and other aspects often acount for more than $70 \%$ of the increase in social labor productivity. However, in the following years, the contribution of endogeneous effect to labor productivity growth declined. In fact the backbone of the Vietnamese economy are enterprises. Nevertheless, most of enterprises in Vietnam are small-scale, donot focus on the application of technological advances. They do not have many creative ideas to increase labor productivity and impove the competitiveness in the market (Tuan, Thanh, \& Loc, 2018). This causes endogeneous productivity to not maintain sustainable growth. If this situation does not improve, Vietnamese enterprises will not be able to compete with large corporations in the region. Consequently, the economy depends on stronger countries such as Singapore, Malaysia, Thailand and other countries. This is what Vietnam does not want. Hence, to avoid that challenge, it is required for Vietnam enterprises to be aware of competition and enhanced their competitiveness by focusing on technological innovation.

The contribution of the static shift effect to Vietnam's labor productivity growth over the past time has been quite stable. Vietnam is an agricultural country, so agricultural labor account is of very high proportion, from $59 \%$ in 2005 to $40 \%$ in 2017 . In the period from 2005 to 2017 , the average contribution of static effect remains at 2 digits. This result reflects Lewis's theory of the shifting of labor from agriculture to industry in a newly industrialized country, when there is a large surplus of agricultural labor (Lewis, 1954).

Finally, dynamic effect has contributed to the growth of social labor productivity by a very small amount in most years. It indicates that the growth rate of labor productivity in the industrial and service sectors has ben delayed, lower than the rate of growth in the agricultural sector, creating a structural burden on the economy. This burden stems mainly from the characteristics of the Vietnamese labor force. With the advantage of cheap and abundant labor but not yet highly skilled, industrial products are often more labor intensive than technology and capital. This situation makes labor productivity growth slow. Meanwhile, the agricultural sector reduced a large part of the labor force due to the shift to the modern sector. Simultaneously, this area tends to use biotechnology and machinery and equipment in production, so labor productivity grows faster. The structural burden will continue to emerge and exist if the industrial and service sectors fail to improve productivity. 


\subsection{Results}

The relationship between productivity and competitiveness will be test through the Granger method. During the analysis of labor productivity, the authors have separated productivity into three parts: static effect, dynamic effect and endogeneous effect. The Granger test will be used to determine that among the three divisions constituting labor productivity, which one has the most impact on competitiveness. Variables in the model include: Growth of labor productivity (GLP), static shift effect (SSE), dyamic shift effect (DSE), endogeneous effect (ENE) and global competitiveness index (GCI).

\subsubsection{Results of Unit Root Test}

As mentioned above, when conducting the Granger test, unit root tests should be performed as a required condition to check the stationarity of data series. The study uses the ADF (Augmented Dickey Fuller) to test the stationarity of observed variables. The test results show that all research variables are statinary at the original level, I(0), with significance levels of $10 \%$ (See Table 3 ).

\subsubsection{Results of Granger Test}

Granger tests are conducted for 4 models: (1) GCI and SSE; (2) GCI and DSE; (3) GCI and ENE; (4) GCI and GLP. The variables in the model were determined optimal lags through the AIC standard with 3 different lags (See Table 4).

The results of testing the relationship between labor productivity and GCI scores in Vietnam shows similar variation. However, when separating labor productivity into three effects, this relationship indicates more clearly that the impact of labor productivity on GCI is mainly caused by endogeneous effect, not by static effect or dynamic effect. Endogeneous labor productivity affected GCI at all the three lags 1, 2, 3. In 2006, endogeneous productivity accounted for $75 \%$ of total labor productivity growth, the GCI score of $3.89 / 7$. In the period from 2010 to 2014 , Vietnam's industry has quikly recovered and returned to the leading position of growth in the economy. Along with that there were a series of macroeconomic reform policies, restructuring the banking system and equitization of state-owned enterprises that were not operating effectively. Those positive adjustments have made endogeneous labor productivity a key factor in contributing to social labor productivity growth. During that period, the global competitiveness score also got higher and always reached above 4/7. According to the World Bank, Vietnam's economy is highly risk resistant thanks to high domestic demand and export-oriented manufacturing. Nevertheless, the rate of population aging in Vietnam is getting faster and faster, the agricultural labor force also accounts for a large proportion in the economy. That forces Vietnam to improve labor skills to create more productive jobs in the future (WB, 2020).

In the relationship between social labor productivity and competitiveness in Vietnam, the static shift effect has not shown its role. This is consistent with the reality of economic growth in Vietnam over the past time. In the early stages of industrialization, the labor productivity in the non-agricultural sector was very high. This means that as long as there is a shift of labor from the agricultural sector to the non-agricultural sector, labor productivity will immediately increase. Anyway, growth in this direction is not an advantage will be highly promoted if the factors of the dynamic shift and endogeneous productivity develop sustainably.

Table 3: Unit root test results for panel data

\begin{tabular}{|l|c|c|c|c|c|}
\hline Variables & GCI & SSE & DSE & ENE & GLP \\
\hline ADF & $-4.04^{* *}$ & $-2.96^{*}$ & $-5.67^{* * *}$ & $-3.36^{* *}$ & $-3.39^{* *}$ \\
\hline
\end{tabular}

Note: ${ }^{* * *},{ }^{* *}$ and ${ }^{*}$ indicates significant at $1 \%, 5 \%$ and $10 \%$ level of significance based on t-statistics.

Table 4: Results of Granger test

\begin{tabular}{|l|c|c|c|c|}
\hline Model & Lags & $\mathbf{1}$ & $\mathbf{2}$ & $\mathbf{3}$ \\
\hline \multirow{3}{*}{1} & $\mathrm{GCl} \rightarrow \mathrm{SSE}$ & 0.3 & 0.41 & 0.66 \\
\cline { 2 - 5 } & $\mathrm{SSE} \rightarrow \mathrm{GCl}$ & 0.02 & 1.31 & 0.6 \\
\hline \multirow{2}{*}{3} & $\mathrm{GCl} \rightarrow \mathrm{DSE}$ & 0.59 & 1.93 & 2.43 \\
\cline { 2 - 5 } & $\mathrm{DSE} \rightarrow \mathrm{GCl}$ & 2.74 & 2.15 & 2.56 \\
\hline \multirow{2}{*}{4} & $\mathrm{GCl} \rightarrow \mathrm{ENE}$ & 0.5 & $6.44^{* *}$ & 2.79 \\
\cline { 2 - 5 } & $\mathrm{ENE} \rightarrow \mathrm{GCl}$ & $10.52^{* * *}$ & 2.73 & $2.22^{*}$ \\
\cline { 2 - 5 } & $\mathrm{GCl} \rightarrow \mathrm{GLP}$ & 0.81 & $7.36^{* *}$ & 2.03 \\
\hline
\end{tabular}

Note: ${ }^{* * *},{ }^{* *}$ and ${ }^{*}$ indicates significant at $1 \%, 5 \%$ and $10 \%$ level of significance based on t-statistics. 


\section{Conclusion and Policy Recommendations}

Labor productivity and competitiveness are two central issues of an integrated economy. Considering their relationship is also finding the best solution to solve the problem. Research results show that dynamic effect has not contributed much to labor productivity growth in Vietnam. This means industries with both dyamic and high growth rates are few and not strong enough to help Vietnam improve labor productivity. Hence, in order to improve its competitiveness, Vietanm should fucus on renewing the education system towards developing thinking capacity, creative capacity; fostering industrial manners, organization, discipline, the spirit of cooperation, self-esteem, trust, community character, conscience and civic responsibility. It must be detemined that this is a very difficult task that cannot be completed in a short time. But it is necessary to do it regularly, continuously, persistently, extensively from the the early childhood education, primary school to high school and university so that these qualities naturally absorb and become the self-conscious habit of everyone. Not only that, Vietnam also needs to have a proper strategy and mindset on training and developing human resources towards globalization on the basis of formulating and adjusting vocational policies; labor demand forcasting policies according to occupations and qualifications; implementing policies to attract all economic sectors so that they actively participate in the field of human resource training for the country.

Besides, the results also shows that endogeneous factors have significantly contributed to the growth of labor productivity, thereby affecting competitiveness. Endogeneous growth can be promoted through mobilizing, exploiting and using rationally and effectively resources; improving business capabilities and executive management capacity. Doing this requires a strong State, a state that has the capacity to formulate and implement consistent and transparent policies. A State must consider enterprises as a breakthrough and as the subject of activities that create knowledge and technology. The government plays an important role in supporting the growth of businesses by building a perfect, accessible economic information system; designing policies in the direction of honoring and encouraging enterprises that tend to invest in the long term; protecting intellectual property rights and creating equality in access to production factors of economic sectors.

Improving labor productivity in order to enhance national competitiveness is considered one of the core issues in governing and developing socio-economic activities to ensure the sustainable development and affirm the country's economic position in the international market. Through two methods of shift share analysis and Granger test, the results of the analysis are very significant for the comments on the correlation between the process of labor productivity growth and competitiveness. However, the drawback of these methods is that they are less predictable for the future, so it is necessary to study this relationship in other approaches.

\section{References}

Anh, N. T. T. (2007). Assessing the contribution of economic sectors and economic restructuring to labor productivity growth in Vietnam. Hanoi, Vietnam: Ministry of Planning and Investment.

Auzina-Emsina, A. (2014). Labour productivity, economic growth and global competitiveness in post-crisis period. ProcediaSocial Behavioral Sciences, 156(26), 317-321.

Baumol, W. J. (1967). Macroeconomics of unbalanced growth: The anatomy of urban crisis. The American Economic Review, 57(3), 415-426.

Borja-Bravo, M., García-Salazar, J. A., \& Skaggs, R. K. (2013). Mexican fresh tomato exports in the North American market: A case study of the effects of productivity on competitiveness. Canadian Journal of Plant Science, 93(5), 839-850.

Carayannis, E., \& Grigoroudis, E. (2014). Linking innovation, productivity, and competitiveness: Implications for policy and practice. The Journal of Technology Transfer, 39(2), 199-218. doi:10.1007/s10961-012-9295-2

CMA. (2015). Productivity and Competition: A summary of the evidence. Retrieved from The National Archives, Kew, London. www.nationalarchives.gov.uk/doc/open-governmentlicence/

Dong, N. T. (2018). The contribution of the Industrial sector in labor productivity growth in Vietnam Journal of Science, Ho Chi Minh Open University, 61(4), 107-116.

Duda, J., Gasior, A., \& Alebaite, I. (2017). Innovation of Polish Micro and small enterprises and trade credit. Transformations in Business Economics, 16(3).

Fabricant, S. (1942). Employment in Manufacturing, 1899-1939: An Analysis of Its Relation to the Volume of Production. Cambridge, MA: National Bureau of Economic Reseach. https://www.nber.org/books/fabr42-1

Fagerberg, J. (2000). Technological progress, structural change and productivity growth: A comparative study. Structural Change Economic Dynamics, 11(4), 393-411.

Granger, C. W. (1969). Investigating causal relations by econometric models and cross-spectral methods. Econometrica: Journal of the Econometric Society, 424-438.

GSO. (2020). General Statistics Office of Vietnam. Retrieved from https://www.gso.gov.vn/Default_en.aspx?tabid=491

Gujarati, D. N. (2004). Basic Econometrics. New York, NY: McGraw-Hill Companies.

Ivanová, E., \& Čepel, M. (2018). The impact of innovation performance on the competitiveness of the Visegrad 4 countries. Journal of Competitiveness, 10(1), 54. DOI: 10.7441/ joc.2018.01.04 
Krugman, P. (1994). The age of diminishing expectations. Washington, DC: Washington Post Company.

Le, N. H., Duy, L. V. Q., \& Ngoc, B. H. (2019). Effects of Foreign Direct Investment and Human Capital on Labour Productivity: Evidence from Vietnam. Journal of Asian Finance, Economics and Business, 6(3), 123-130. https://doi.org/10.13106/ jafeb.2019.vol6.no3.123

McGowan, M. A., Andrews, D., Criscuolo, C., \& Nicoletti, G. (2015). The future of productivity. Paris, France: OECD.

Mihaela, S. (2016). Competitiveness and economic growth in Romanian regions. Journal of Competitiveness, 8(4), 46. DOI: 10.7441/joc.2016.04.03

Nam, M. V. (2013). Situation and factors which affected the competitiveness of small and medium sized enterprises in Dong Thap. Journal of Science, Can Tho University, 45-53.

Nguyen, P. A., Nguyen, A. H., Ngo, T. P., \& Nguyen, P. V. (2019). The Relationship between Productivity and Firm's Performance: Evidence from Listed Firms in Vietnam Stock Exchange. Journal of Asian Finance, Economics and Business, 6(3), 131140. https://doi.org/10.13106/jafeb.2019.vol6.no3.131

Porter, M. E. (2008). On competition. Cambridge, MA: Harvard Business Press.

Schwab, K., \& Sala-i-Martin. (2017). Global Competitiveness Report, 2016-2017. Cologny, Switzerland: World Economic Forum.

Sergej, V. (2016). The Impact of The Structural Funds on Competitiveness of Small and Medium-Sized Enterprises.
Journal of Competitiveness, 8(4), 30. DOI: 10.7441/joc.2016. 04.02

Soltes, V., \& Gavurova, B. (2015). Modification of performance measurement system in the intentions of globalization trends. Polish Journal of Management Studies, 11.

Syrquin, M. (1984). Resource reallocation and productivity growth. In: Economic structure and performance (pp. 75-101). Amsterdam, the Netherlands: Elsevier.

Syrquin, M., \& Chenery, H. (1986). Industrialization and growth. A comparative study. In Chapter Patterns of structural change. Oxford, UK: Oxford University Press.

Te, N. Q., \& Dong, N. T. (2013). Measuring growth of labor productivity in Vietnam by shift-share analysis of structure of industries. Journal of Economic Development, 218, 37-47.

Timmer, M. P., \& Szirmai, A. (2000). Productivity growth in Asian manufacturing: The structural bonus hypothesis examined. Structural Change Economic Dynamics, 11(4), 371-392.

Tuan, N. A., Thanh, N. M., \& Loc, T. T. (2018). Technology Management and Challenges of Vietnamese Enterprises in the International Market. Journal of Asian Finance, Economics and Business, 5(1), 43-52. http://dx.doi.org/10.13106/jafeb.2018. vol5.no1.43

Virglerova, Z., Dobeš, K., \& Vojtovič, S. (2016). The perception of the state's influence on its business environment in the SMEs from Czech Republic. In: Administratie si Management Public.

World Bank. (2020). Vietnam Overview. Retrieved from https:// www.worldbank.org/en/country/vietnam/overview 